ELENI CHITA, M.Sc. ${ }^{1}$

E-mail: chitaelen@gmail.com

EFI DRIMILI, Ph.D. ${ }^{1}$

E-mail: efidrim@yahoo.gr

ZOI GAREIOU, M.Sc. ${ }^{1}$

E-mail: zgareiou@gmail.com

CHRISTINA MILIOTI, Ph.D. ${ }^{1}$

E-mail: cmilioti@mail.ntua.gr

ANTIGONI VRANNA, Ph.D. ${ }^{1}$

E-mail: avranna@civil.auth.gr

STAVROS POULOPOULOS, Ph.D. ${ }^{2}$

E-mail: stavros.poulopoulos@nu.edu.kz

EFTHIMIOS ZERVAS, Ph.D. ${ }^{1}$

(Corresponding author)

E-mail: zervas@eap.gr

${ }^{1}$ Laboratory of Technology and Policy of Energy

and Environment, School of Science and Technology

Hellenic Open University

Parodos Aristotelous 18, 26335 Patra, Greece

2 Environmental Science \& Technology Group (ESTg)

Chemical and Materials Engineering Department

School of Engineering and Digital Sciences

Nazarbayev University

010000, Nur-Sultan, Kazakhstan
Transport Economics Original Scientific Paper Submitted: 6 May 2019 Accepted: 19 Feb. 2020

\title{
IMPACT OF ECONOMIC CRISIS ON PASSENGER TRANSPORTATION - CASE OF TRAVELLING TO THE GREEK MAINLAND FROM CRETE
}

\section{ABSTRACT}

The Greek economic crisis of 2009 onwards has affected all aspects of social and economic life of the country, including transportation. The present study focuses on the impact of economic crisis on the long distance transportation between the island of Crete in Greece, the largest Greek island and one of the largest in the Mediterranean Sea, and the Greek mainland. A questionnaire survey was used to investigate the opinions of the Cretans on the way the economic crisis influenced their transportation to the Greek mainland. The results of the survey show that the frequency of the Cretans' travels was significantly limited, owing to the increased direct or indirect associated cost, due to the economic crisis. Especially for those who struggled to make ends meet, the transportation to the mainland dropped to the bare essentials. Furthermore, the respondents deemed that the deregulation of the Greek maritime and airline markets was also to blame for the high fares, thus they favoured a regulated public transport sector and were against privatization. Inevitably, financially vulnerable individuals were the most preoccupied with these issues. A feeling of isolation and exclusion was revealed by the sample on occasions when the scheduled trips were cancelled by the operators due to exogenous parameters.

\section{KEYWORDS}

transport; economic crisis; Greece; Crete; public opinion; Principal Components Analysis;

\section{INTRODUCTION}

The Greek economy has been experiencing a severe economic crisis since 2009. The stringent austerity measures have resulted in adverse effects on the economic, political and social life in Greece. According to the official data, the unemployment rate rose from $9.6 \%$ in 2009 to $27.5 \%$ in 2013 and $21.5 \%$ in 2017 . The gross domestic product at market prices per capita in current prices decreased from 21,800 euro in 2008 to 16,200 euro in 2015 and remained at 16,800 euro in 2017 [1]. Additionally, job insecurity has increased dramatically, whereas working conditions have deteriorated [2, 3]. For example, the official part-time employment rate grew from $6.1 \%$ in 2009 to $9.5 \%$ in 2015 [1].

The economic crisis made its imprint also on the transport sector. In 2012, almost four out of ten Greek citizens (37\%) did not travel at all, and the majority of them $(72 \%$ out of $37 \%)$ cited financial 
reasons [4]. On the other hand, almost seven out of ten European citizens (71\%) at EU27 level reported having travelled or having been away from home for at least one night during the same year. Furthermore, less than one out of two Europeans (46\%) who did not travel in 2012, justified their decision on economic reasons [4]. Between 2008 and 2013, the total number of domestic passengers handled by all Greek airports dropped by almost three million or $-23.2 \%$ [5]; domestic flights reported a sharp decrease for the same period (over -25\%), shrinking further the low-profit margin market [4]. Similar figures exist for the maritime transport service: the number of total passengers who used the Greek ports decreased by $-20.4 \%$ between 2008 and 2012, while vehicle transportation by sea went down by $-7.5 \%$ for the same period [6]. As a result, both air and sea operators were forced to cut down on their costs by reducing the personnel, deteriorating the quality of services, increasing of fares, using smaller fleets, applying fewer routes per destination, etc. New actors, except low-cost carriers such as Ryanair, are quite unlikely to enter the Greek air and sea navigation markets due to high operating costs and low profit margins, whereas the generally unpredictable and unstable economic context of the country does not fuel such investments [4]. It should be also noted that although national elections are normally held in Greece every four years, these have been held seven times during the last fifteen years.

Taking into consideration the linkage between the economic crisis and transportation, as described earlier, the present work aims to investigate public perceptions regarding the way that the economic crisis has affected the travels of the citizens from the insular country to the mainland. The case study in the present work is the island of Crete, the questionnaire is addressed to its inhabitants and as travels are considered, the travels from Crete to the mainland. Particularly an off-Crete trip refers to the trip made by ship or airplane from Crete to anywhere on the
Greek mainland and it is not restricted to the Athens wider area (including Piraeus, the maritime port of Athens). The paper is organized as follows. First, there is a brief overview of recent literature on the economic crisis and transport justifying the purpose and the novelty of the study. This is followed by a section where the methodology is described (questionnaire, sample size, collection method). In the next section, the results of the descriptive analysis and the results of the chi-square test of independence are presented and discussed. Finally, the conclusion section follows, which includes the main findings of the research and their policy implications.

\section{LITERATURE REVIEW}

The island of Crete in Greece is a special case due to its size and population and its geographical position (Figure 1). In particular, it is the biggest Greek island and the second biggest island in the East Mediterranean Sea. Its resident population reaches approximately 623,000 inhabitants, which makes up to $6 \%$ of the total Greek population [7]. Crete comprises four prefectures: Heraklion (305,490 residents), Chania (156,585 residents), Rethymnon (85,609 residents) and Lassithi $(75,381$ residents) [7].

Crete can be reached from the mainland by sea and air. The main maritime ports are Heraklion, Chania, Rethymnon, Agios Nikolaos and Sitia. As to the airports, these exist in Heraklion, Chania and Sitia. Obviously, the locals have quite limited choices for travelling to the mainland Greece.

The link between revenues (for example Gross Domestic Product per capita) or the economic growth and transportation has been studied in several countries, such as the cases of domestic air passenger traffic in Brazil [8], in Chile [9], in China [10] or in Mexico [11]. These authors found in most cases a causality between GDP/capita to transportation; i.e. an increase in GDP/capita leads to an increase in traffic demand.



Figure 1 - Crete's location in Greece along with its infrastructure (maritime ports and airports) 
Moreover, some works studied the impact of economic crisis on the transport sector, such as the impact of the crisis on the airline transport demand [12], on household transport expenditure [13], and on fuel demand [14].

The previous studies are in most cases based on aggregated numerical data. Additionally, several countries applied the National Travel Surveys to capture trends of resident travels [15-18]. However, these surveys are not based on a common methodology allowing comparisons among countries [19-21].

In the case of Greece, the literature review has revealed a limited number of studies related to how people perceive the impact of economic crisis on long distance transportation. Sambracos and Rigas 2007 conducted surveys, using questionnaires, at three different times $(1996,2000,2005)$. The questionnaire was addressed to passengers travelling by air and sea to the Aegean islands. By analysing the passengers' preferences related to their modal choice, the effect of transport market deregulation on increasing competitiveness between the two modes was indicated [22]. The competitive relationship of these two different transport modes (air and sea transport) has been also investigated by Rigas et al. in 2011, during the period of the economic crisis. The study concluded that boosting passenger demand in the sea transport market requires reduction in travel time, while improving passenger demand by air requires reduction in fare prices, especially during the current economic crisis [23]. Sambriacos et al. in 2014 analysed the statistical data related to the demand for passenger shipping transport in specific regional areas to the insular country and the trend of specific financial indicators. The research findings highlighted the correlation of the growth rate at regional level (measured by the Gross Domestic Product, unemployment rate, and the construction activity) and the tourist growth with the demand for passenger transport services [24].

There are also some papers investigating the impact of the economic crisis on the urban mobility of users in Greece, based on data derived from questionnaires [25]. These studies report an overall reduction in the mobility of travellers, due to the income reduction and the increase in unemployment level [26]. Concerning the transport mode used, a decrease in the market share of the most expensive transport modes, such as private cars [27] and taxis [28] has been observed, whereas there has been an increase in the public transport mode share [26].
Moreover, an increase in the demand for sustainable transport modes (bicycle, walking), mainly due to the economic crisis and the respective income reduction has been reported [27]. However, all the aforementioned studies focus on the impact of the economic crisis on the mobility in an urban environment.

What is missing today, is the opinion of the users about the impact of the economic crisis on their own travels, focusing on long-distance journeys, where the studies that appear in the literature are rather limited. The current study aims to fill this gap.

\section{MATERIALS AND METHODS}

Data collection was based on a questionnaire survey conducted from December 2016 to February 2017 in the capitals of the four prefectures of Crete, on different weekdays and at different hours of the day. All the respondents interviewed were adults $(>18$ years old) and residents of Crete.

All interviews were carried out by the same person (the first author of this study), who was adequately trained. The questionnaires were filled by the interviewer, based on the respondent's answers, yet at no time did she disclose her functional title, neither intervened, nor manipulated the respondent's judgment. Thus, a satisfactory degree of reliability was achieved during the entire process.

Based on simple random sampling, 365 in-person structured interviews were conducted in total; yet 35 questionnaires $(9.6 \%)$ were excluded, due to inadequate data provision. Thus, the final sample included 330 completed valid questionnaires. The sampling error is given by the following formula [29]:

$$
n=\frac{z^{2} \cdot p \cdot(1-p) \cdot N}{M E^{2} \cdot(N-1)+z^{2} \cdot p \cdot(1-p)}
$$

where:

$M E$-desired margin of error;

$n$-sample size ( $n=330$ in this survey);

$N$-population size $(N=623,000$ adult population of Crete);

$p$-preliminary estimate of the proportion in the population (a maximum value of 0.50 was assumed);

$z \quad$-two-tailed value of the standardized normal deviate (for $95 \%$ confidence interval, the value of $z$ is equal to 1.96).

The above sample leads to a confidence level of $5.4 \%$, in a $95 \%$ confidence interval. Additionally, the sample's origination is relative to the resident 
population of each prefecture (150 questionnaires from Heraklion, 80 from Chania, 50 from Rethymnon and 50 from Lassithi).

Table 1 presents the final sample, also showing the corresponding values for Crete and Greece (including all the mainland and the islands and Crete as well), as these are documented in the latest official statistics [6]. This table shows that the sample is representative for residence, gender and age distribution, yet there are some small differences in the case of educational level and marital status. In total, the sample is considered to be quite representative and the conclusions can be used for the entire Cretan population.

The distributed questionnaire outlined the perceptions of the resident population of Crete during the Greek economic crisis regarding travelling from Crete to the mainland and comprised four sections: frequency of travelling, cost of transportation, comfort of transportation, and socio-demographic information. The questions were close-ended, of ordinal variables on a five-point scale ('Not at all', 'Little', 'Quite' or 'Enough', 'Much' and 'Very much'), corresponding to a degree of agreement/disagreement with the question or to a likelihood of the statement to take place.

The first part included a series of questions that explored the respondent's general trends concerning the purpose and the frequency of travelling outside Crete, as well as the main factors influencing their decision. In this section, the respondents were also asked to state whether they had restricted their transportation activities to Greek mainland due to the economic recession. The second part collected the respondents' beliefs about the associated price of their trip: ticket prices, price of vehicle transportation for reaching their final destination, etc. It also recorded the respondents' opinions about the deregulation of the Greek sea and air navigation markets, as well as envisioning the consequences of the privatization of Crete's maritime ports and airports (the privatization took place quite a few months after the collection of the questionnaires). The third section assessed the degree of accessibility to Crete's infrastructure (maritime ports and airports) and the amenities offered (e.g. availability and cost of parking). It also recorded the sense of exclusion of the respondents in the case of trip cancellations due

Table 1 -Characteristics of the final sample and comparison with the data of the 2011 national census (Crete and Greece) for those aged $>18$

\begin{tabular}{|c|c|c|c|c|}
\hline & & Sample [\%] & Crete $>18$ years $[\%]$ & Greece $>18$ years $[\%]$ \\
\hline \multirow{2}{*}{ Gender } & Men & $49.09(n=162)$ & 51.01 & $48.47 *$ \\
\hline & Women & $50.91(n=168)$ & 48.99 & $51.53 *$ \\
\hline \multirow{4}{*}{ Marital status } & Singles & $30.6(n=101)$ & 24.50 & 26.20 \\
\hline & Married & $62.1(n=205)$ & 62.86 & 62.87 \\
\hline & Divorced & $4.9(n=16)$ & 3.38 & 3.71 \\
\hline & Widows/-ers & $2.4(n=8)$ & 8.42 & 9.19 \\
\hline \multirow{4}{*}{ Educational level } & $\leq 12$ years education & $72.1(n=238)$ & 78.79 & 81.20 \\
\hline & Post 12-year education & $4.8(n=16)$ & 5.49 & 5.88 \\
\hline & University degree & $16.1(n=53)$ & 13.29 & 11.24 \\
\hline & M.Sc./Ph.D. & $7.0(n=23)$ & 2.42 & 1.66 \\
\hline \multirow{6}{*}{ Age (years) } & $18-24$ & $13.6(n=45)$ & 10.71 & 9.63 \\
\hline & $25-34$ & $21.5(n=71)$ & 18.63 & 17.32 \\
\hline & $35-44$ & $20.3(n=67)$ & 19.30 & 18.43 \\
\hline & $45-54$ & $17.2(n=57)$ & 15.87 & 16.58 \\
\hline & $55-64$ & $11.4(n=37)$ & 13.47 & 14.41 \\
\hline & $>65$ & $16.1(n=53)$ & 22.01 & 23.63 \\
\hline Unemployment & & $19.5(n=64)$ & & 17.9 \\
\hline \multirow{4}{*}{$\begin{array}{l}\text { Prefecture of } \\
\text { residence }\end{array}$} & Heraklion & $45.45(n=150)$ & 49.0 & \\
\hline & Chania & $24.24(n=80)$ & 25.10 & \\
\hline & Rethymnon & $15.15(n=50)$ & 13.7 & \\
\hline & Lassithi & $15.15(n=50)$ & 12.2 & \\
\hline
\end{tabular}


to bad weather or strikes. The final section of the questionnaire was designed to capture relevant demographic information (gender, age, prefecture of residence, etc.).

The main trends of the responses were calculated for each question. A $\chi^{2}$ analysis for each variable showed the relation between these questions and the socio-demographic parameters. Next, a Principal Component Analysis was performed to reveal the possible groups of questions.

\section{RESULTS AND DISCUSSION}

The present section presents and discusses the results of the descriptive analysis, the chi-square test of independence and of the principal component analysis applied to the variables of the questionnaire. It is divided into two different subsections. In subsection 3.1 the results of the descriptive analysis of the respondents' views related to several aspects of passengers' transportation are presented, and the effect of the socioeconomic factors on the participants' views is investigated. In subsection 3.2 the variables' grouping through the PCA method is presented. Common aspects of the transportation are identified making it easier to interpret the data and to further elaborate them.

\subsection{Analysis of respondents' views}

The present subsection presents the results of the analysis of several components related to passengers' transportation, such as purpose and frequency of travel, factors affecting the frequency of travelling from Crete to the Greek mainland, factors discouraging passengers to transport their own vehicle to the Greek mainland, and satisfaction with the accessibility to Crete infrastructure. In addition, the respondents' opinions about the cost of ferryboat and airline tickets is presented as well as their proposal for a fair price, about the deregulation of transport market and about the impact of exogenous factors on the cancelation of their trips and the sense of exclusion that the locals may feel.

\section{Purpose and frequency of travel}

The first part of the questionnaire highlights the general trends concerning the purpose and the frequency of travelling from Crete to the mainland (Figure 2, where the percent (\%) corresponds to the proportion of the respondents per reason of travel, with several choices allowed, and the frequency corresponds to the number of journeys of off-Crete trips per year). About six out of ten respondents $(58.8 \%)$ indicated holidays/entertainment as the most important reason for off-Crete trips, with an average frequency of 2.3 times/year, one third of them reported family obligations/relations (2.45 times/year on average), $29 \%$ of the sample travelled for professional reasons (2.2 times/year on average), $12.4 \%$ for medical reasons (2.6 times/year), $11.2 \%$ for education reasons (3.6 times/year), and finally $18.5 \%$ of the respondents reported other personal reasons (2.2 times/year).

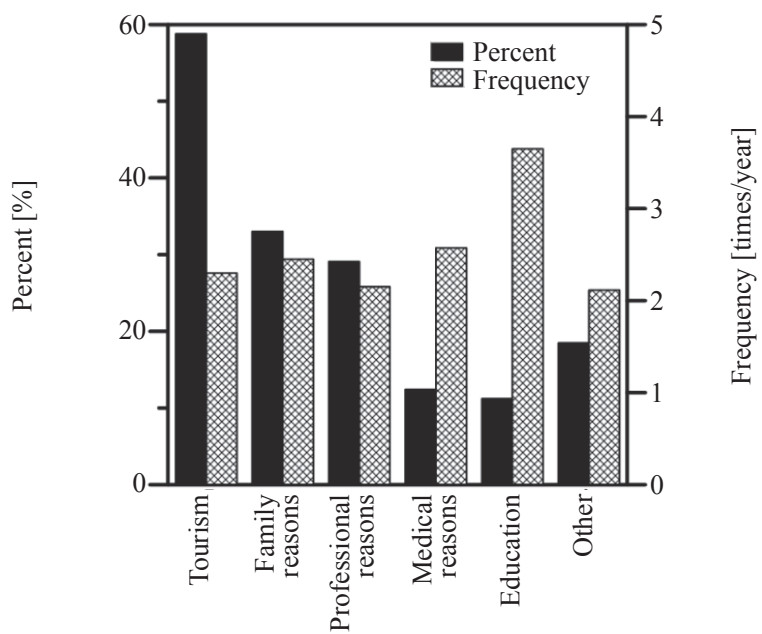

Figure 2 - Purpose and frequency of travelling outside Crete to Greek mainland

Some significant statistical associations existed between the frequency of travel and respondents' personal characteristics. The frequency of travel for tourism was found to be positively associated with the educational level (Sig. $=0.042$ ); frequency of travel for education was associated with the family status (Sig. $=0.04$ ), with the singles and the divorced reporting a higher number of trips made (4.04 and 5.0 times/year, respectively).

\section{Factors affecting the frequency of travelling}

from Crete to the Greek mainland

The purpose of this part of the questionnaire was to record whether the respondents have reduced the frequency of their trips due to the Greek economic crisis and, furthermore, to highlight other major factors associated with this trend.

Almost all respondents (98.9\%) stated that the Greek economic crisis was the primary cause for reducing the frequency of their off-Crete trips (Figure 3a), while only a very small minority of $1.1 \%$ maintained the same level of trips. This decrease was statistically significant with age (Sig. $<0.001$, 

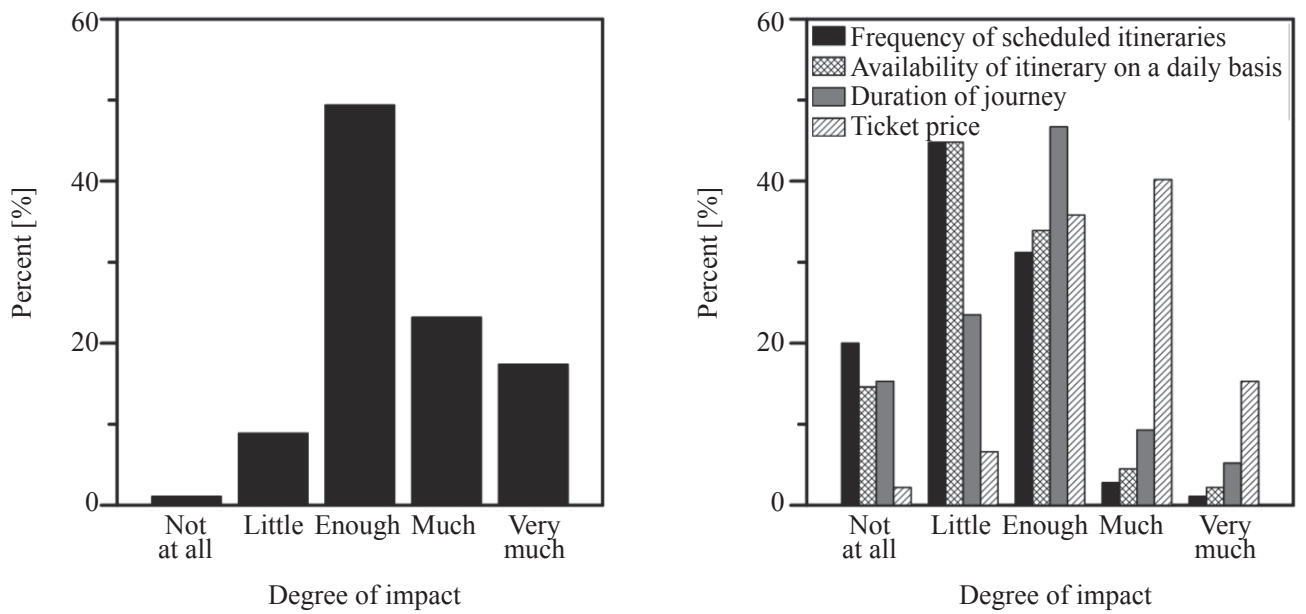

Figure 3 - a) Degree of impact of economic crisis on outside Crete travels; b) Factors discouraging citizens from travelling more often outside Crete

the decrease of trips increased with age), marital status (Sig. $=0.007$, higher decrease for the married than the singles), number of children per family (Sig. $=0.046$, the decrease increased with the number of children) and profession (Sig. $=0.016$, higher decrease for public servants, lower for students). Also, it should be noted that the vast majority of the respondents $(85.1 \%)$ reported that they wished to travel more frequently outside Crete. This was associated with age $(\mathrm{Sig} .=0.03)$, with the middle-aged indicating the strongest desire.

Figure $3 b$ depicts the factors which discouraged the resident population from travelling outside Crete. For the vast majority of the sample (97.8\%), the fares affected their willingness to travel more often, in accordance with the previous finding that the economic crisis decreased the number of trips. Eighty-five percent of the respondents considered the duration of the journey (obviously by ship and usually overnight, lasting 6-8 hours depending on the weather), as an obstacle (60\% answered Enough to Very much). About $85 \%$ of the respondents stated that not being able to travel on the day they wished to travel affected the frequency of their voyages ( $40 \%$ answered Enough to Very much). On the other hand, $80 \%$ of the sample was satisfied with the existing availability and frequency of the scheduled arrivals/departures to/from Crete by air and sea, and they did not consider frequency and availability as limiting factors. It should be noted that, in 2012, there were about 53 flights per day (annually averaged) connecting Crete with the rest of the country, and a significant, but seasonally varying number of international flights [30]. Also, there were about three ferry routes per day between Crete and Piraeus, the main maritime port of Athens, the capital of Greece [31]. Previous works identified different demand levels between airport and ferry journeys. This difference is mainly affected by the ticket prices (air tickets are more expensive), the duration of the journey (airplanes offer shorter journeys) and the coverage of the journeys (ferries offer a significantly larger network) [23].

The duration of the journey as a limiting factor was associated with age (Sig. $=0.047$, the limitation increased with age), marital status (Sig. $=0.021$, singles found it more discouraging), and professional activity (Sig. $=0.005$, students emphasized more); fares as a discouraging factor was associated with age (Sig. $=0.036$, elder people were affected to a greater extent); the availability to travel the day the travellers wanted to travel as a discouraging factor was associated with age and profession: senior individuals (Sig. $=0.006$ ) and students (Sig. $=0.001)$ considered this parameter more significant.

\section{Factors discouraging passengers to transport their own vehicle to Greek mainland}

The next questions were related to the factors preventing passengers from transporting their personal vehicles to Greek mainland in order to use them during their stay outside Crete or reach their final destination if they travel outside the Athens area (Figure 4).

The quasi-totality of the respondents $(98 \%)$ believed that the overall price for a trip from Crete to the Greek mainland using a car is expensive. Also, the same percentage of the respondents $(97 \%)$ believed that ferryboat car-tickets are overpriced. Consequently, that fact affected their choice to transport their car to the Greek mainland. This opinion was associated with the work status (Sig. $=0.0023$ ); 


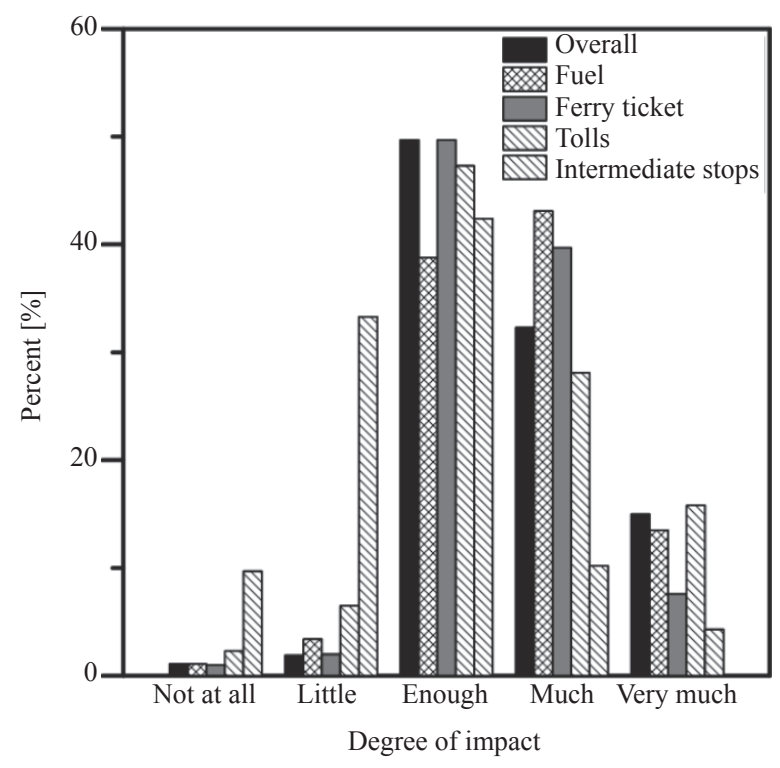

Figure 4-Factors affecting the transportation of vehicles

job-seekers and temporarily employed were more affected. Since travel mobility can be an aid to reduce unemployment, special low-price policies should be applied to the unemployed residents. Additionally, almost all respondents (95\%) reported high fuel prices. This parameter was associated with gender (Sig. $=0.013$, women expressed this view more firmly than men), and prefecture of residence (Sig. $=0.032$, residents of the cities with no port were more definite on this issue, obviously because they have to travel to the nearest port). Moreover, nine out of ten $(91 \%)$ respondents indicated the high prices of motorway tolls. This opinion was associated with gender (Sig. $=0.037$, women supported more strongly this statement than men), and educational level (Sig. $=0,043$, this opinion decreased with the level of education). Finally, $90.3 \%$ of the respondents agreed that other expenses after arriving to Athens in order to reach their final destination, such as cost of lunch, drinks, etc. during their trip also contribute to leaving their car in Crete.

On the whole, the Greek economic crisis has had a multifaceted effect on the Cretans' travelling habits, especially for individuals belonging to the most vulnerable groups.

\section{Accessibility to Crete infrastructure (airports/maritime ports)}

Concerning the existing network of public transportation of Crete to access its maritime ports and airports, almost seven out of ten respondents $(69.2 \%)$ and four out of ten (43\%) were 'quite', or 'much', or 'very much' satisfied, respectively. This satisfaction (or dissatisfaction) was directly connected with the respondents' residence (Sig. $<0.001$ ). As expected, the residents of Heraklion, the biggest town of Crete, with direct access to both a maritime port and an airport, reported increased satisfaction in the public transportation network compared to the residents of Rethymnon, with just a maritime port at their disposal. The residents of Agios Nikolaos, where there is no maritime port or airport available, were the most dissatisfied. This satisfaction was also associated with the profession of the respondents (Sig. $=0.013$ ): students were found to be the most satisfied group of travellers, whereas the retired people were the most dissatisfied. The latter finding is obvious; the difficulty to move and the comfort people demand increase with age $[32,33]$.

More than a half (57\%) of the respondents preferred to use their private vehicles to access Crete maritime ports and airports, while $25 \%$ used taxi and only $18 \%$ opted for public transport. The use of a private vehicle was associated with marital status $($ Sig. $=0.019)$, prefecture of residence $($ Sig. $<0.001)$ and profession (Sig. $=0.013$ ): married people, residents of small towns and private employees tend to prefer their private cars. However, about $90 \%$ of the respondents reported that the parking price is quite to very high.

The previous findings show that the use of public transport or private car depends strongly on the social class of the users and that cost is a significant parameter for their decision. Moreover, the results show the general insufficiency of public transport in the Cretan cities.

\section{Ticket prices}

A series of questions asked for the respondents' opinions about the cost of ferryboat and airline tickets, as well as their proposal for a fair price, which would motivate them to travel more often. At the time of the research, the price of a one-way ferry passenger ticket was about $€ 35$ (economy class), of a one-way ferry car-ticket about $€ 85$, and that of a one-way air ticket ranged between $€ 50$ and $€ 150$. Choosing to issue return tickets as well, the price is about double or a little less. Figure $5 a$ depicts the sample's proposed price range for a one-way trip. On average, a reasonable price for a ferryboat passenger ticket (economy class), according to the respondents, is considered to be between $€ 10-30$ (median of $€ 25$ ), for a ferryboat car-ticket between $€ 20-40$ (median of $€ 35$ ) and finally, for a one-way air-voyage around between $€ 40$ and 60 (median of 

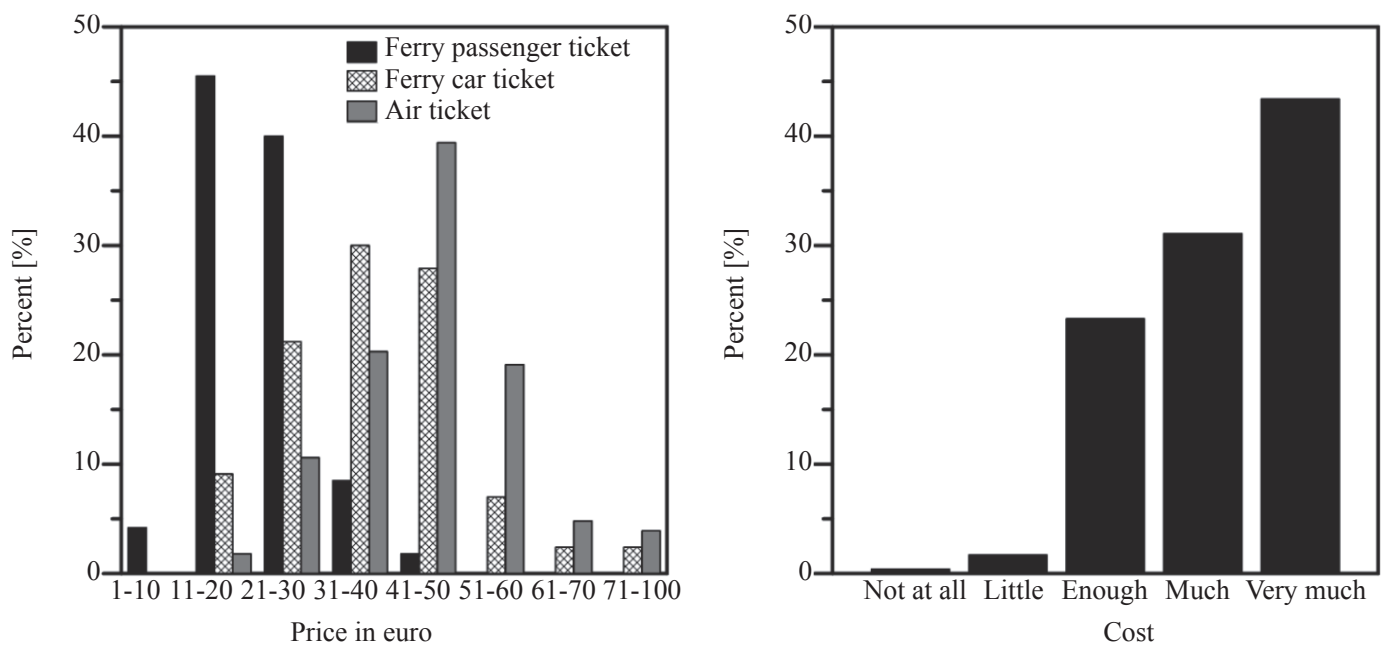

Figure 5 - a) Proposed price range for one-way ferry (passenger and car) and air tickets; b) Evaluation of the price of the "last minute" one-way air ticket

$€ 50)$. However, these proposed prices may be even lower today, as the economic crisis in Greece is still ongoing and the people's revenues continue to decrease. The crucial role of ticket prices in shaping the demand for transport services, especially in times of economic crisis, has been highlighted in the previous works concerning the case of Greece [23, 24]. In an attempt to financially support the inhabitants of the islands, the Greek government adopted in July 2018 a measure for subsidizing ticket fares for their transportation from and to the mainland. This measure was initially implemented on a small pilot basis for mainly small islands. Gradually, this measure was planned to extend to other island regions; however, it has not yet been implemented for the residents of Crete.

Several relations were statistically significant between the proposed prices and the socio-economic characteristics of the sample. Young people, singles, low-income groups, low educated and professionally insecure individuals (unemployed or part-time employed, students) were those who claimed lower prices, indicating that the economic crisis does not have the same impact on all citizens. This finding is in line with the results of [27], that found that mobility behaviour changes during the economic crisis are income dependent.

Thus, the ticket price discounts could be provided by airline and maritime companies to such groups of residents (for example to unemployed residents) for their transportation from and to the mainland, especially during high demand periods, when ticket prices are higher. It is crucial that the design of policies should focus on the social needs, especially for the island residents, as their connection with the mainland serves the basic social functions such as trips for medical reasons, education and employment purposes.

Furthermore, the respondents were asked to evaluate the price of the "last minute" air ticket, which is normally purchased in emergency situations, where no true alternatives exist (Figure 5b). Almost the entire sample ( $98 \%$ of the respondents) believed that the "last minute" air ticket is expensive. Women, younger respondents, job-seekers and public servants expressed themselves more profoundly, showing again that the economic crisis has not the same impact on all social classes.

\section{Control and ownership of the transport sector}

This part of the questionnaire investigated the consequences of the deregulation of the Greek navigation market. In addition, the respondents commented on the effects of a potential privatization of the Crete infrastructure (maritime ports and airports) and the preferred ownership of the transport sector. It should be noted that a part of the infrastructure was under privatization at the time of the questionnaire survey.

As shown in Figure 6, more than three quarters of the sample believed that the deregulation of the Greek maritime and airline markets has led to increased fares in both means $(78 \%$ and $75 \%$, respectively). Additionally, six out of ten respondents believed that privatizing Crete maritime ports and airports would lead to further increase in the prices of ferry and airline tickets (62\% and 59\%, respectively). It is quite interesting that there is no relationship of the above variables with the socio-economic characteristics of the sample, indicating that 




Figure 6-Effect of the deregulation and of potential privatization on fares

all the social classes had quite common beliefs about privatization. The public perception of the deregulation of the Greek navigation market is in contrast with the research findings of the previous works suggesting positive effects of deregulation in the Aegean transport passenger market [23]. Positive effects highlighted by previous works are related to improved competition within the same mode and between other modes and to the subsequent reduction in ticket prices.

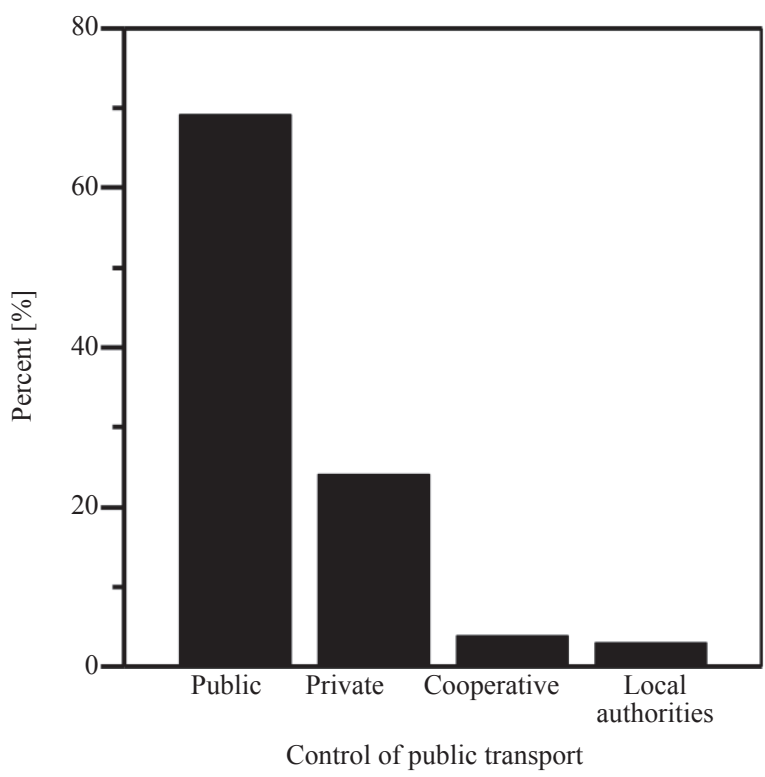

Figure 7 - Respondents' perceptions about the control and the ownership of the Greek transport sector
Figure 7 shows the respondents' opinions about the ownership of the transport sector. A great majority $(69 \%)$ claimed that air and sea lines should be owned and controlled only by the state, while only one fourth of the sample (24\%) preferred private control or/and private ownership. Moreover, the respondents highlighted a deep mistrust of the local municipalities or/and cooperatives, since only $4 \%$ and $3 \%$, respectively preferred them as owners of the transport companies. Therefore, the resident population of Crete is against privatizations and encourages a more active participation of the state in the transport sector. These preferences are possibly associated to the previous outcome: strong dissatisfaction derived from the expensive fares, as a result of the deregulation of the Greek maritime and airline markets. The major ports of Greece such as Piraeus follow the administration model of landlord ports. For the regional ports, the Greek government is in the process of evaluating the most appropriate way to administrate them.

The ownership of the transport sector was associated with age (Sig. $=0.028)$ and education (Sig. $=0033$ ); the younger and higher educated respondents emphasized more the public character of the Greek transport sector.

The preference of the respondents to the public character of state-owned services has been also highlighted in previous surveys, conducted among the residents of Athens and concerning the ownership of several services such as water management and transport management [34, 35].

\section{Feeling of exclusion}

As an island, Crete quite often encounters adverse weather conditions which delay or even cancel the scheduled trips (both by sea and air). Furthermore, occasional strikes consist of an additional contributing factor for trip cancellations. This part of the questionnaire examined the respondents' belief for the impact of weather on the cancelation of their trips and the sense of exclusion that the locals feel due to the aforementioned reasons. More than nine out of ten respondents thought that bad weather conditions hinder their off-Crete voyages to the Greek mainland and felt marginalized when this occurred (91.8\% and $95.5 \%$, respectively).

However, it should be noted that the reported sense of exclusion is non-evidence based, since only ten ferry routes (Heraklion - Piraeus) were cancelled in 2012, which corresponds to just 2.5\% of the total annual ferry routes. Similarly, only 


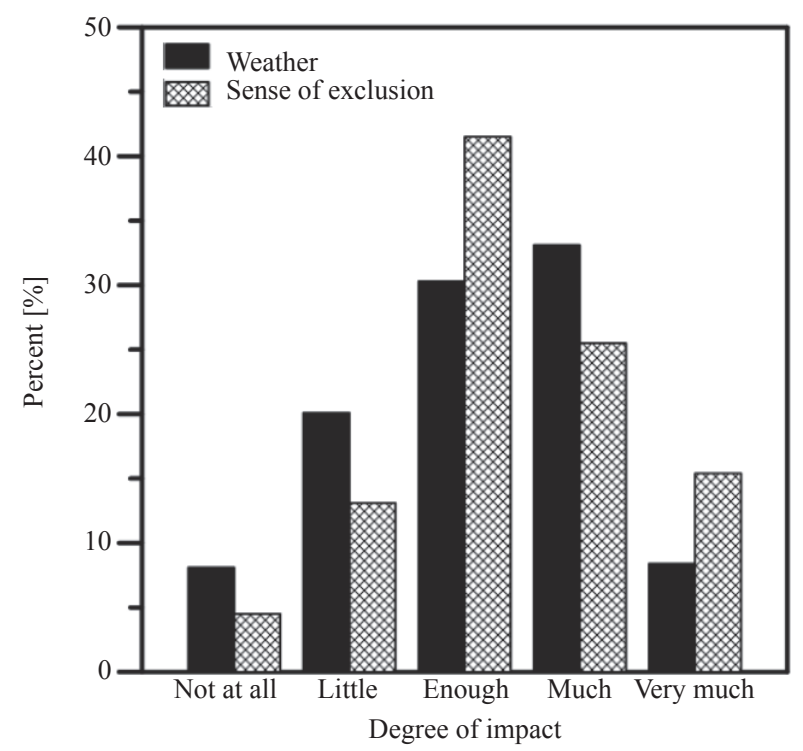

Figure 8-Impact of the cancelation of trips due to bad weather and on the feeling of exclusion

eleven scheduled flights from Heraklion to Athens were cancelled in the same year, which is also a very small number compared to the eight regular flights scheduled on a daily basis. Therefore, the expressed sense of exclusion is more a conception than reality. However, there are cases, such as emergency conditions or medical reasons when this sense is undeniable. Every prefecture of Crete has a central hospital; however, moving the patient to the Athens central hospitals is very often necessary for specialized medical care.
Travel difficulties due to bad weather and the sense of exclusion were both associated with gender (Sig. $=0.021$ and $<0.001$ respectively), age (Sig. $=0.015$ and 0.036$)$ and location of residence (Sig. $<0.001$ and 0.02 ): women, elderly individuals and residents of the smaller cities with fewer facilities showed the highest belief that bad weather would cancel their trip, as well as the highest sense of exclusion. The link among transport related social exclusion, demographic factors (gender, age), availability of transport services, and global economy was also emphasized by [33].

\subsection{Principal component analysis}

For the purposes of this study, a Principal Component Analysis (PCA) was performed, in order to group the questions in clusters. Four PCs were extracted, representing almost $60 \%$ of the variability of the original data. The KMO criterion and Bartlett test of sphericity were applied to measure the question and sampling adequacy. The result of this analysis revealed satisfactory values $(\mathrm{KMO}=0.609$ and $\mathrm{p}<0.001$ on Bartlett test (approx. chi-square $=163.94$, $\mathrm{df}=10$ ). The internal consistency of each group of questions of a component was measured by applying the Cronbach's test (Table 2), whereby values greater than 0.7 were considered as satisfactory.

Table 2 - The extracted PCs, Rotated Component Matrix

\begin{tabular}{|c|c|c|c|c|c|}
\hline \multirow{2}{*}{ Question } & \multicolumn{4}{|c|}{ Component } & \multirow{2}{*}{ Cronbach's Alpha } \\
\hline & PC1 & $\mathrm{PC} 2$ & PC3 & PC4 & \\
\hline DEREGULATION_INCREASED_SHIP_FARES & 0.743 & 0.216 & 0.136 & -0.116 & \multirow{4}{*}{0.772} \\
\hline DEREGULATION_INCREASED_PLANE_FARES & 0.703 & 0.230 & 0.126 & -0.107 & \\
\hline PRIVATISATION_INCREASE_SHIPS & 0.815 & -0.206 & -0.089 & 0.113 & \\
\hline PRIVATISATION_INCREASE_PLANES & 0.815 & -0.191 & -0.086 & 0.101 & \\
\hline SATISFACTION_FREQUENCY & -0.033 & 0.729 & -0.053 & -0.056 & \multirow{3}{*}{0.791} \\
\hline SATISFACTION_DURATION & 0.071 & 0.861 & -0.056 & 0.094 & \\
\hline SATISFACTION_COMFORT & -0.007 & 0.839 & -0.140 & 0.135 & \\
\hline WEATHER & -0.072 & -0.197 & 0.570 & 0.112 & \multirow{4}{*}{0.803} \\
\hline ISOLATION & 0.085 & -0.022 & 0.950 & 0.123 & \\
\hline PARKING_AIR_SECURITY & -0.012 & -0.011 & 0.932 & 0.450 & \\
\hline PARKING_PORT_SECURITY & 0.085 & -0.022 & 0.950 & 0.123 & \\
\hline PARKING_AIR_COST & -0.084 & -0.036 & -0.089 & 0.813 & \multirow{4}{*}{0.768} \\
\hline PARKING_PORT_COST & 0.010 & -0.047 & 0.007 & 0.802 & \\
\hline COST_OTHER_FINAL_FUEL & 0.028 & 0.101 & 0.114 & 0.581 & \\
\hline COST_OTHER_FINAL_TOLLS & 0.019 & 0.053 & 0.069 & 0.538 & \\
\hline
\end{tabular}

Rotation Method: Varimax with Kaiser Normalization. 
PC1 is named "Deregulation and privatization" and consists of variables related to the impact of deregulation of the Greek navigation market and the privatization of the Crete maritime ports and airports to the prices of tickets. All variables of deregulation and privatization contribute positively, and quite equally, to PC1. PC2 represents the "Satisfaction" of the respondents with the travels' frequency, duration and comfort. All variables of $\mathrm{PC} 2$ contribute positively, and quite equally to it. The variables involved in the calculation of $\mathrm{PC} 3$, which represents the "Sense of exclusion/ security", are related to external factors that influence the travel frequency such as weather, security and sense of exclusion. All variables positively load the PC3, but the variables of exclusion and security have the strongest impact. Finally, PC4, which is named "Other cost", represents the impact of cost to travel decrease. The variables of PC4 are related to the fuel price, tolls price during the travel and the price of parking in maritime port or airport parking, which have the strongest impact comparing to the other two variables.
The above clusters reveal that the opinions of Crete residents about all aspects of deregulation and privatization, satisfaction about the trips from Crete to mainland Greece, sense of exclusion, and cost follow the same trend.

One-way ANOVA was performed to investigate the impact of the socio-demographic characteristics (age, marital status, kind of family, education, profession, work status, personal income, family income) on the four PCs (Table 3). The impact of gender, number of children and number of family members was investigated by performing an independent t-test (Table 4); the above variables are dichotomous (gender) or have been transformed into dichotomous (number of children: 0-1 child coded as 1 , more than one child coded as 2 and number of family members: $1-2$ members coded as 1 , more than two members coded as 2).

These methods revealed the existence of a relationship between PC2 and the variables of profession and work status, as well as of the number of family members. Workers of the private sector and those with high professional insecurity are those

Table 3 - Effect of socio-demographic characteristics on the extracted PCs

\begin{tabular}{|c|c|c|c|c|c|c|}
\hline \multicolumn{2}{|c|}{ ANOVA } & Sum of squares & df & Mean square & $\mathrm{F}$ & Sig. \\
\hline \multirow{8}{*}{ PC2_SATISFACTION } & \multicolumn{6}{|c|}{ Profession } \\
\hline & Between groups & 9.759 & 7 & 1.394 & 5.516 & 0.000 \\
\hline & Within groups & 81.125 & 321 & 0.253 & & \\
\hline & Total & 90.883 & 328 & & & \\
\hline & \multicolumn{6}{|c|}{ Work status } \\
\hline & Between groups & 7.192 & 7 & 1.027 & 3.893 & 0.000 \\
\hline & Within groups & 60.706 & 230 & 0.264 & & \\
\hline & Total & 67.898 & 237 & & & \\
\hline \multirow{12}{*}{ PC3_SECURITY } & \multicolumn{6}{|c|}{ Age } \\
\hline & Between groups & 6.089 & 4 & 1.522 & 5.690 & 0.000 \\
\hline & Within groups & 86.944 & 325 & 0.268 & & \\
\hline & Total & 93.033 & 329 & & & \\
\hline & \multicolumn{6}{|c|}{ Education } \\
\hline & Between groups & 6.154 & 7 & 0.879 & 3.258 & 0.002 \\
\hline & Within groups & 86.880 & 322 & 0.270 & & \\
\hline & Total & 93.033 & 329 & & & \\
\hline & \multicolumn{6}{|c|}{ Profession } \\
\hline & Between groups & 6.913 & 7 & 0.988 & 3.691 & 0.001 \\
\hline & Within groups & 85.886 & 321 & 0.268 & & \\
\hline & Total & 92.799 & 328 & & & \\
\hline
\end{tabular}


Chita E, et al. Impact of Economic Crisis on Passenger Transportation - Case of Travelling to the Greek Mainland from Crete

Table 4 - Effect of dichotomous variables on extracted PCs

\begin{tabular}{|c|c|c|c|c|c|c|c|c|c|c|}
\hline & & \multicolumn{9}{|c|}{ Independent samples test } \\
\hline & & \multicolumn{2}{|c|}{$\begin{array}{l}\text { Levene's Test for } \\
\text { equality of variances }\end{array}$} & \multicolumn{7}{|c|}{ T-test for equality of means } \\
\hline & & \multirow[t]{2}{*}{$\mathrm{F}$} & \multirow[t]{2}{*}{ Sig. } & \multirow[t]{2}{*}{$\mathrm{t}$} & \multirow[t]{2}{*}{ df } & \multirow[t]{2}{*}{$\begin{array}{c}\text { Sig. } \\
\text { (2-tailed) }\end{array}$} & \multirow[t]{2}{*}{$\begin{array}{c}\text { Mean } \\
\text { difference }\end{array}$} & \multirow[t]{2}{*}{$\begin{array}{l}\text { Std. error } \\
\text { difference }\end{array}$} & \multicolumn{2}{|c|}{$\begin{array}{c}95 \% \text { Confidence } \\
\text { interval of the } \\
\text { difference }\end{array}$} \\
\hline & & & & & & & & & Lower & Upper \\
\hline \multirow{3}{*}{ 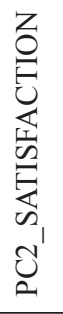 } & \multicolumn{10}{|c|}{ Number of family members } \\
\hline & $\begin{array}{l}\text { Equal variances } \\
\text { assumed }\end{array}$ & 0.339 & 0.561 & -3.140 & 328 & 0.002 & -.0180 & 0.057 & -0.294 & -0.067 \\
\hline & $\begin{array}{c}\text { Equal variances } \\
\text { not assumed }\end{array}$ & & & -3.160 & 322.468 & 0.002 & -0.180 & 0.057 & -0.293 & -0.068 \\
\hline \multirow{3}{*}{ 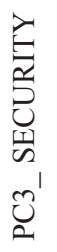 } & \multicolumn{10}{|c|}{ Number of children } \\
\hline & $\begin{array}{c}\text { Equal variances } \\
\text { assumed }\end{array}$ & 1.120 & 0.291 & -2.374 & 328 & 0.018 & -0.221 & 0.093 & -0.405 & -0.038 \\
\hline & $\begin{array}{l}\text { Equal variances } \\
\text { not assumed }\end{array}$ & & & -2.746 & 48.372 & 0.008 & -0.221 & 0.080 & -0.383 & -0.059 \\
\hline
\end{tabular}

with the lower satisfaction with the frequency, duration, and comfort of the trips. There is also a relation between PC3 and the variables of age, education, profession and the number of children. Those who do not have a stable job, with a lower level of education, or with more children, are more vulnerable to external factors (such as weather, sense of isolation, or security) to reduce the number of travels.

\section{CONCLUSION}

The present work summarizes the major findings of the statistical survey (330 completed questionnaires in the final sample) conducted from December 2016 to February 2017 in Crete, Greece, exploring the views of the residents population about the impacts of the economic crisis on their off-Crete trips to the Greek mainland.

The results show that the Cretans' decision for a trip to Greek mainland is heavily affected by the economic crisis and also by deregulation. They think that poor value for money is offered by both means of transport (air and sea). The overall cost is a significant factor to travel from Crete to mainland Greece. Especially for those who struggle to make ends meet (pensioners, unemployed or temporarily employed, public servants, families with several children), travel frequency is dropped to the bare essential trips (education, medical reasons, family obligations). This drop, apart from the reduction of the monthly income, is also due to high travel cost, attributed by the respondents to the deregulation of the Greek maritime and airline markets. In fact, according to the respondents, the current fares for both means of transport are $50-100 \%$ more expensive than they should be. Lower income groups, low educated and professionally insecure individuals are those who highlighted more this disproportion. As a result, the Cretans favour a more active participation of the Greek state in the transport sector and are against its privatization, because this has led to further increase in ticket prices.

A sense of isolation and exclusion exists among the residents of Crete due to the trip cancellation from exogenous parameters (weather, strikes); women, elder individuals and residents of smaller cities with no facilities (maritime ports/airports) felt most the degree of exclusion.

The Principal Components Analysis was used to reveal the main components. Four components were extracted, representing almost $60 \%$ of the variability of the original data. The first component is named "Deregulation and privatization", the second "Satisfaction" of the respondents with the travels' frequency, duration and comfort, the third "Sense of unsafety" related to factors influencing the travel frequency such as weather, safety and sense of isolation and the fourth "Other costs", representing the impact of cost to travel decrease. Profession, work status, and the number of family members were 
shown to have an impact on the second component, while age, education, profession and the number of children on the third one.

The research findings could be a useful tool for policy makers as well as for ferry and airline companies to provide the appropriate framework to increase the attractiveness of travels mainly through ticket price reduction policies; these policies are of particular value and importance to citizens in a time of economic crisis. It is also crucial that the design of policies focused on the social aspect, especially for island residents, as their connection with the mainland serves the basic social needs, such as health and education. Future research can be carried out in the same area in order to investigate the potential changes in the perceptions of the passengers in conjunction with the changes in the macroeconomic factors. In addition, valuable conclusions can be drawn by conducting similar surveys in smaller island regions where access to the mainland is restricted and the economies of those areas are less developed.

\section{EАENH XHTA ${ }^{1}$ \\ ЕФН $\triangle$ PIMYAH ${ }^{1}$ \\ Z $\Omega$ ГАРEIOY ${ }^{1}$

 \\ ANTIГONH BPANNA ${ }^{1}$

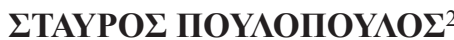

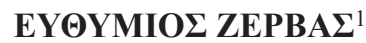

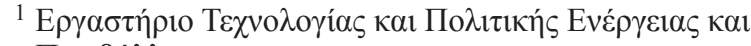

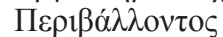

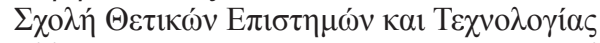

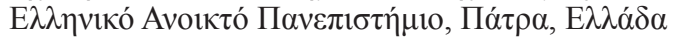

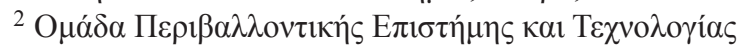





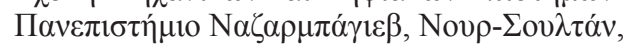

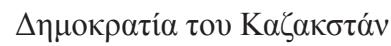

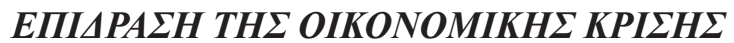

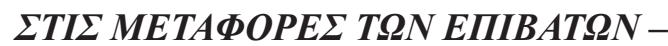

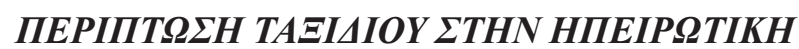 ЕАЯAАA АПО THN КРНTH}

\section{ПЕРІАНЧН}

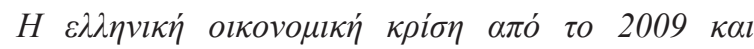

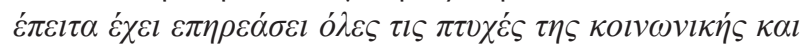

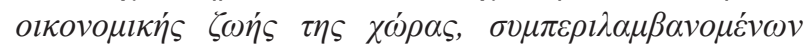

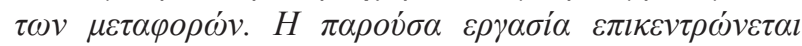



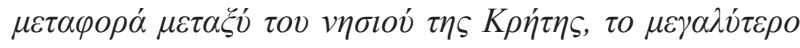

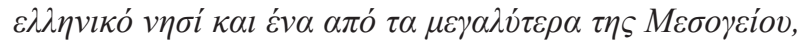

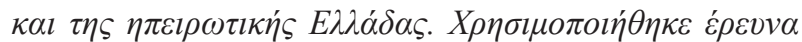

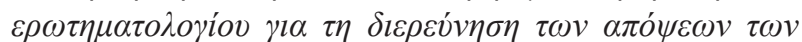

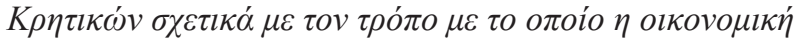



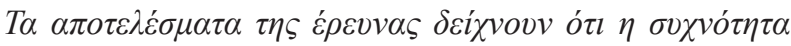

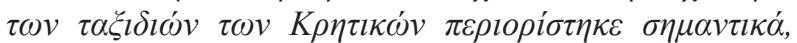

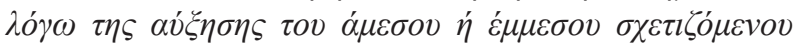

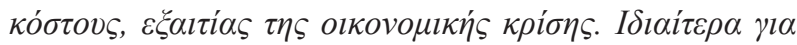

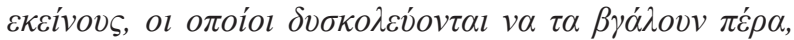

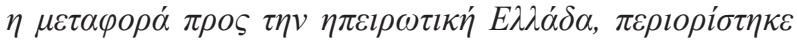

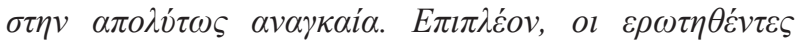

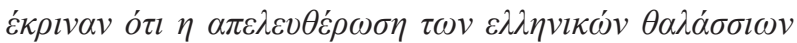

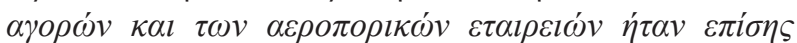

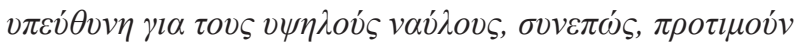



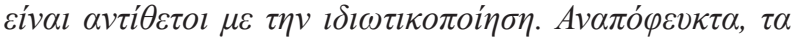

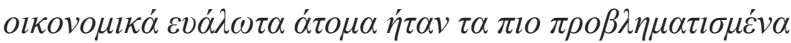

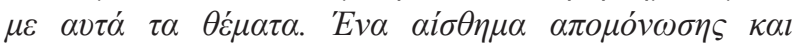

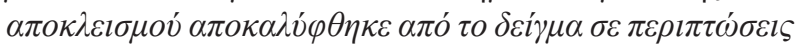

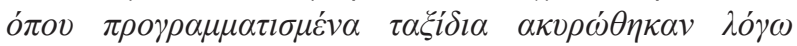
$\varepsilon \xi \xi \omega \gamma \varepsilon v \omega \dot{v} \pi \alpha \rho \alpha \mu \dot{\varepsilon} \tau \rho \omega v$.

\section{KEY WORDS}

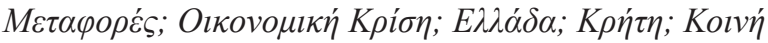



\section{REFERENCES}

[1] Eurostat. Eurostat Online Database (various series). Available from: https://ec.europa.eu/eurostat/data/database [Accessed February 15th 2019].

[2] Labor Inspectorate (LI). [Labor Inspectorate Annual Report: Year 2012]. Available from: http://www.ypakp.gr/ uploads/docs/6810.pdf [Accessed September $2^{\text {nd }} 2018$ ]. Greek.

[3] Labour Institute of the General Confederation of Greek Workers (LI-GCGW). [Greek Economy and Employment]. Annual Report, 2013. Available from: http:// www.inegsee.gr/wp-content/uploads/2014/02/files/ ekthesh-15email.pdf [Accessed September $2^{\text {nd }} 2018$ ]. Greek.

[4] European_Commission. Flash Eurobarometer 334: Attitudes of Europeans Towards Tourism; 2013. Available from: http://ec.europa.eu/commfrontoffice/publicopinion/flash/fl_370_en.pdf

[5] Hellenic Civil Aviation Authority (HCAA). Annual Airport Statistical Data 1994-2014. Available from: http:// www.ypa.gr/en/profile/statistics/yearstatistics/ [Accessed September $\left.2^{\text {nd }} 2018\right]$.

[6] EL.STAT Online Database (various series). Available from: http://www.statistics.gr/el/statistics/ind [Accessed February $\left.15^{\text {th }} 2019\right]$.

[7] EL.STAT. Population Census 2011. General Population Census 2011. Available from: http:/www.statistics.gr/ portal/page/portal/ESYE/PAGE-census2011

[8] Fernandes E, Pacheco RR. The causal relationship between GDP and domestic air passenger traffic in Brazil. Transportation Planning and Technology. 2010;33(7): 569-581.

[9] Brindis MAR, Mejía-Alzate ML, Aguirre SZ. La causalidad entre el crecimiento económico y la expansión del 
transporte aéreo: un análisis empírico para Chile. Revista de economía del Rosario. 2015;18(1): 127-144.

[10] Hu Y, Xiao J, Deng Y, Xiao Y, Wang S. Domestic air passenger traffic and economic growth in China: Evidence from heterogeneous panel models. Journal of Air Transport Management. 2015;42: 95-100.

[11] Brida JG, Rodríguez-Brindis MA, Zapata-Aguirre S. Causality between economic growth and air transport expansion: Empirical evidence from Mexico. World Review of Intermodal Transportation Research. 2016;6(1): 1-15.

[12] Dobruszkes F, Van Hamme G. The impact of the current economic crisis on the geography of air traffic volumes: An empirical analysis. Journal of Transport Geography. 2011;19(6): 1387-1398.

[13] Cascajo R, Olvera LD, Monzon A, Plat D, Ray JB. Impacts of the economic crisis on household transport expenditure and public transport policy: Evidence from the Spanish case. Transport Policy. 2018;65: 40-50.

[14] Bakhat M, Labandeira X, Labeaga JM, López-Otero X. Elasticities of transport fuels at times of economic crisis: An empirical analysis for Spain. Energy Economics. 2017;68: 66-80.

[15] CSO. 2011. National Travel Survey (NTS); 2009.

[16] GOV.UK. 2013. The 2012 National Travel Survey (NTS). Available from: https://www.gov.uk/government/publications/national-travel-survey-2012

[17] Santos A, McGuckin N, Nakamoto HY, Gray D, Liss S. 2011. Summary of Travel Trends: 2009 National Household Travel Survey. U.S. Department of Transportaion, Federal Highway Administration, Report No. FHWAPL-11-022, 2011. Available from: https://nhts.ornl. gov/2009/pub/stt.pdf

[18] Transport Scotland. Scottish Transport Statistics No 32 2013 Edition. Available from: https://www.transport. gov.scot/publication/scottish-transport-statistics-no-322013-edition/

[19] Axhausen K. Preparing for the long of it: Methodological research for an European survey of long distance travel. Paper presented at: TRB Conference: Personal Travel: The long and short of it, June-July 1999, Washington, $D C ; 2000$.

[20] Stopher PR, Alsnih R, Wilmot CG, Stecher C, Pratt J, Zmud J, Mix W, Freedman M, Axhausen K, Lee-Gosselin M, Pisarski AE, Broeg W. Standardized Procedures for Personal Travel Surveys, The National Academies Press, NCHRP Report 571, 2008.

[21] Violland M. 2011. Travel / mobility surveys: some key findings (No. 2/2011). Available from: https://www.itfoecd.org/sites/default/files/docs/sp201102.pdf
[22] Sambracos E, Rigas K. Passenger reactions to market deregulation: First results from the experience of the Greek islands market. Journal of Air Transport Management. 2007;13: 61-66.

[23] Rigas K, Sambracos E, Gatzoli A. Air and Sea Transport: Competition Strategies Under Normal and Economic Crisis Environments. SPOUDAI Journal of Economics and Business. 2011;61(3-4): 65-84.

[24] Sambracos E, Maniati M. Financial Crisis \& Passenger Shipping: Evidence from Greece. SPOUDAI Journal of Economics and Business. 2014;64(2): 40-49.

[25] Milioti C, Pnevmatikou A, Karlaftis M. Mobility Patterns, User Behavior and Financial Crisis: An Exploratory and Revealed Preference Analysis. European Transport Conference, September 2014, Frankfurt, Germany; 2014.

[26] Efthymiou D, Antoniou C. Understanding the effects of economic crisis on public transport users' satisfaction and demand. Transport Policy. 2017;53: 89-97.

[27] Papagiannakis A, Baraklianos I, Spyridonidou A. Urban travel behaviour and household income in times of economic crisis: Challenges and perspectives for sustainable mobility. Transport Policy. 2018;65: 51-60.

[28] Milioti C, Karlaftis M, Akkogiounoglou E. Traveler perceptions and airline choice: A multivariate probit approach. Journal of Air Transport Management. 2015;49: 46-52.

[29] Kothari CR. Research methodology, methods and techniques. Second revised ed. India: New Age International Publishers; 1990.

[30] YPA. Air Traffic Statistics 2012. Available from: http:// www.ypa.gr

[31] HCG. Hellenic Coast Guard, various data. Online Database. Available from: http://www.hcg.gr/ [Accessed May $25^{\text {th }} 2018$.

[32] Metz DH. Mobility of older people and their quality of life. Transport Policy. 2000;7(2): 149-152.

[33] Alsnih R, Hensher DA. The mobility and accessibility expectations of seniors in an aging population. Transportation Research Part A: Policy and Practice. 2003;37(10): 903-916.

[34] Drimili E, Gareiou Z, Vranna A, Poulopoulos S, Zervas E. An integrated approach to public's perception of urban water use and ownership of water companies during a period of economic crisis. Case study in Athens, Greece. Urban Water Journal. 2019;16(5): 334-342.

[35] Nikolidaki M, Kaika D, Zervas E. Social Acceptance of the Privatization of Infrastructure in Greece. Utopia. 2016;115: 157-169. 